\title{
Multi-Criteria Performance Assessment for Semi-Transparent Photovoltaic Windows in Different Climate Contexts
}

\author{
Gigih Rahmandhani Setyantho (D), Hansaem Park and Seongju Chang *
}

Citation: Setyantho, G.R.; Park, H.; Chang, S. Multi-Criteria Performance Assessment for Semi-Transparent Photovoltaic Windows in Different Climate Contexts. Sustainability 2021, 13, 2198. https://doi.org/10.3390/ su13042198

Academic Editor: Steve

Kardinal Jusuf

Received: 1 February 2021

Accepted: 15 February 2021

Published: 18 February 2021

Publisher's Note: MDPI stays neutral with regard to jurisdictional claims in published maps and institutional affiliations.

Copyright: (c) 2021 by the authors. Licensee MDPI, Basel, Switzerland. This article is an open access article distributed under the terms and conditions of the Creative Commons Attribution (CC BY) license (https:/ / creativecommons.org/licenses/by/ $4.0 /)$.
Department of Civil and Environmental Engineering, Korea Advanced Institute of Science and Technology, Daejeon 34141, Korea; setyanthogr@kaist.ac.kr (G.R.S.); saem@kaist.ac.kr (H.P.)

* Correspondence: schang@kaist.ac.kr

\begin{abstract}
Semi-transparent photovoltaic (STPV) windows, one of the building façade elements, can generate electricity and provide a certain amount of daylight for occupants. Nevertheless, expensive cost and unsatisfying indoor daylight performance in the room are common problems with STPV windows. This study investigates the thermal, daylight, energy, and life-cycle cost performance of STPV windows by considering varied window-to-wall ratios, building orientations, and STPV module types. The electricity balance index (elBI) indicator is proposed as one of the performance evaluation criteria. Two types of building models are established for this study: a rig-test building as the baseline building model and a KAIST campus research facility as the test building model along with the actual measurements and simulations using DesignBuilder. Results show that the STPV window in the Mediterranean climate demonstrates higher efficiency based on the elBI indicator. Decision-making analysis using the analytic hierarchy process and PROMETHEE II found weighting rates of $0.309,0.076$, and 0.465 for elBI, comfort, and cost criteria, respectively. Furthermore, lighting energy consumption becomes a critical variable for STPV module type selection, while a simple $\mathrm{ON} / \mathrm{OFF}$ lighting control system can improve the elBI value by $0.02 \sim 0.04$. Our research findings could potentially improve the decision-making process for building and urban energy systems selection in different climate types.
\end{abstract}

Keywords: photovoltaics; energy-efficient building; thermal comfort; visual comfort; life-cycle cost; decision-making

\section{Introduction}

The building sector, inclusive of residential and commercial sectors, comprises roughly $30 \%$ of globally delivered energy consumption [1]. Several typical strategies for building energy conservation include passive design, active design, and smart energy management targeting energy-efficient buildings. As one of the energy sensitive building elements, the building façade becomes a physical interface between the external and internal building environment. In order to implement a zero energy building (ZEB) concept into reality, a high-performance sustainable façade should be addressed. A sustainable façade is defined as an exterior enclosure that influences energy usage, indoor comfort, occupants' health, and productivity [2].

There are two types of façades such as opaque and glazed façades [2]. A window is a glazed façade that plays an essential role in connecting the indoor and outdoor environment. A window serves as an aesthetic element, a heat and mass transfer medium, and a daylighting penetration interface, showing a significant role in energy consumption in buildings [3]. Combining window and photovoltaic (PV) systems is innovative for supporting the self-powered building concept by harvesting energy from the sun. As a matter of fact, solar façade becomes a familiar term to emphasize solar heat utilization in a building's façade structure [4]. In the last decade, numerous PV materials that possess opaque and even transparent characteristics have been proposed. Significantly, these materials could be integrated with the building facade and are usually called building-integrated 
photovoltaics (BIPV). This technology provides a feasible solution to meet the partial or entire energy demand in a building [5]. Furthermore, BIPV façade application also invokes some challenges in balancing architectural design and energy performance [6].

In brief, there are four common problems in semi-transparent photovoltaic (STPV) deployment as a BIPV façade: expensive cost, unsatisfiable daylight performance for human comfort, low energy performance, and climate-dependent building design. It is also suggested that various performance indicators of building façade design aspects need to be investigated [6,7].

This research aims to identify STPV integrated window selection decision-making by considering energy, thermal comfort, visual comfort, and cost for a building located in different climate types. Furthermore, a new performance indicator, the electricity balance index (elBI), is suggested to evaluate alternative STPV systems' energy performance. An analytic hierarchy process (AHP) and a preference ranking organization method for enrichment of evaluations (PROMETHEE II) are used to rank derived solution strategies in each climate region. Singapore in group A Köppen Climate; Abu Dhabi and Cairo in group B Köppen Climate; Buenos Aires, Chengdu, and Wellington in group C Köppen Climate; and Beijing, Incheon, and Reykjavik in group D Köppen Climate are the alternative locations representing different climate types that are considered in this research.

\section{Related Studies}

Multi-criteria decision analysis (MCDA) is increasingly attractive to deal with sustainable energy system strategies to achieve sustainability goals. These analysis tools would help the decision-makers evaluate potential objectives that are contradictory to each other most of the time. Wang et al. (2009) reviewed past studies related to energy system decision-making, including energy planning, energy allocation, energy exploitation, energy policy, building energy management, and transportation energy system. Results show that economic and environmental aspects were commonly used aspects in energy system decision-making. Significantly, the equal criteria weighting model and AHP method turned out to be the popular ones to decide potentially successful energy system strategies [8].

Siksnelyte-Butkiene et al. (2020) reviewed a more specific field of renewable-energy technology selection in household buildings [9]. Economic, social, technological, and environmental dimensions became the most common assessment criteria for MCDA in household buildings. Among MCDA methods, the following methods were mostly adopted and preferred in energy sector decision-making problems:

1. Analytic hierarchy process (AHP);

2. Techniques for order of preference by similarity to the ideal solution (TOPSIS);

3. Preference ranking organization method for enriching evaluation (PROMETHEE).

TOPSIS is the most frequently used method, while PROMETHEE is one of the most suitable methods to assess energy-related technologies despite its intensive complex calculation and longer calculation time [9].

Various precedent studies used a combination of simulation and MCDA methods. Turcksin et al. introduced the combination between AHP and PROMETHEE to select an optimum policy scenario out of a clean fleet simulation [10]. In the energy sector, Harkouss et al. worked on a simulation plus MCDA combination in order to find the most successful solution for passive/active design [11,12] combined with renewable-energy alternatives [13] which were simulated using TRNSYS. Through these works, a AHP pairwise correlation method was also utilized to define different weighting scenarios. Thus, the elimination and choice expressing the reality III (ELECTRE III) method as one of the outranking methods was utilized for ranking analyzed alternatives based on a weighting scenario. These combination methods turned out to be beneficial for multi-location decisionmaking analysis [11-13]. 


\subsection{Solar Energy Potential of STPV Windows}

There are several studies concerning semi-transparent photovoltaic (STPV) application in buildings. In these studies, various types of STPV such as amorphous silicon STPV [14-24], crystalline silicon STPV [25,26], perovskite cells STPV [27], cadmium telluride PV [28,29], and photovoltachromic PV [30,31] are investigated. In the meantime, crystalline silicon is considered to be the first generation, amorphous silicon and cadmium telluride are classified as the second generation, whereas perovskite and photovoltachromic represent the third generation of PV glazing [32].

\subsection{Building Performance Indicators}

In this section, building performance indicators are reviewed based on the precedent studies on STPV utilization. The indicators could be divided into three categories, namely, energy, comfort, and cost dimension. A summary of STPV-related performance indicators of previous research is presented in Table 1.

\subsubsection{Energy Dimension}

In order to quantify the energy performance of a building, some performance indicators were previously introduced. Most recent studies adopt primary energy consumption (PEC). A PEC indicator may reflect energy consumption focusing on different energy forms, including electricity. PEC could be defined as watt-hour $(\mathrm{kWh})$ or watt-hour per square meter $\left(\mathrm{kWh} / \mathrm{m}^{2}\right)$. Sometimes, a PEC indicator is specified for heating, cooling, ventilation, air-conditioning (HVAC), equipment, and lighting-related energy uses. Energy generation amount $\left(E_{g e n}\right)$ also becomes one of the primary indicators for assessing STPV performance. Such an indicator as saving (Sav) focuses on the energy consumption percentage difference against the baseline building design. A few other indicators such as net energy balance (NEB) [21], energy balance index (EBI) [22], and overall energy consumption (OEC) [20] were also proposed.

\subsubsection{Comfort Dimension}

Comfort in a building could commonly be divided into two categories such as visual comfort and thermal comfort. Typical visual comfort-related indicators used in precedent works are discomfort glare index (DGI) [33], discomfort glare probability (DGP) [34], and useful daylight illuminance (UDI) [35]. Another indicator, $N$-Daylit Area, proposes a quantified area where the illuminance is between 450-2000 lux due to daylight [16]. Window property-related indicators such as visible light transmittance (VLT) are also utilized to assess visual comfort [36].

For thermal comfort, discomfort hours is the most commonly used indicator. This indicator is based on indoor temperature $(t)$ and relative humidity $(\% R H)$. Discomfort hours could be counted when $t$ and $\% R H$ values are within the range of air-conditioning operation or outside of set-point temperatures. An integrated comfort indicator acceptance of the indoor environmental quality (IEA), proposed quantifying an occupant's acceptance based on discomfort hours, $\mathrm{CO}_{2}$ concentration, and total illuminance level [37].

\subsubsection{Cost Dimension}

Most of the precedent works focused on cost saving in electricity price ( $\left.\mathrm{Sav}_{\text {elect }}\right)$ to assess building design cost alternatives. Other works investigate capital cost (CC), payback period (PBP), net present value (NPV), internal rate of return (IRR), energy payback time (EPBT), energy return on investment (EROEI), and discounted payback (DP) as economic indicators. The profitability index (PI) was also proposed by multiplying NPV and investment cost [38]. In the meantime, Moncef et al. proposed life-cycle cost for evaluating energy-efficient buildings [39]. 
Table 1. Summary of building performance indicators adopted in precedent studies.

\begin{tabular}{|c|c|c|c|}
\hline \multirow{2}{*}{ (Ref.) } & \multicolumn{3}{|c|}{ Building Performance Indicators } \\
\hline & Energy Dimension & Comfort Dimension & Cost Dimension \\
\hline [27] & $E_{\text {gen }}$ & UDI, DGP & \\
\hline$[40]$ & $\mathrm{AeC}$ & IEA & \\
\hline [15] & $\mathrm{PEC}_{\text {cool }}, \mathrm{PEC}_{\text {heat }}, \mathrm{PEC}_{\text {HVAC }}, \mathrm{E}_{\text {gen }}$ & & Sav $_{\text {electricity }}$ \\
\hline [41] & PEC, SavPEC & & \\
\hline [17] & $\mathrm{PEC}_{\text {cool, }} \mathrm{PEC}_{\text {heat }}, \mathrm{PEC}_{\text {light }}, \mathrm{E}_{\text {gen }}$ & & \\
\hline [42] & $\mathrm{PEC}_{\mathrm{cool}}, \mathrm{PEC}_{\text {heat }}$, PEC & UDI, DGP & \\
\hline [30] & Sav PEC & & Sav electricity \\
\hline [29] & PEC, Egen & & IRR, NPV, DP \\
\hline [14] & $\mathrm{E}_{\text {gen }}, \mathrm{PEC}_{\text {cool }}, \mathrm{PEC}_{\text {heat }}, \mathrm{PEC}$ & & \\
\hline [16] & $\mathrm{AeC}$ & N-daylit Area \% & \\
\hline [19] & $\mathrm{AeC}_{\text {light }}, \mathrm{AeC}_{\text {cool }}, \mathrm{AeC}_{\text {heat }}, \mathrm{AeC}$ & & \\
\hline$[20]$ & $\mathrm{PEC}_{\text {light }}, \mathrm{PEC}_{\mathrm{cool}}, \mathrm{OEC}$ & UDI & \\
\hline [21] & NEB, AeC & & \\
\hline [22] & EBI & DGI & \\
\hline [23] & PEC, EBI & & \\
\hline [24] & $\begin{array}{c}\text { Egen }_{\text {ge }} \text { PEC }_{\text {fans, }} \text { PEC }_{\text {pumps, }} \\
\text { PEC }_{\text {chillers }}, \text { PEC }_{\text {HVAC }}\end{array}$ & & Sav electricity \\
\hline [25] & $E_{\text {gen }}$, PEC, PEC $_{\text {light }}$ & $\begin{array}{c}\text { t, \%RH, } \\
\text { Discomfort hour }\end{array}$ & \\
\hline [26] & PEC & & $\mathrm{Sav}_{\text {electricity }}, \mathrm{CC}, \mathrm{PBP}$ \\
\hline [28] & AeC, NEB, Sav NEB & & \\
\hline [31] & $\mathrm{PEC}_{\text {cool }}, \mathrm{PEC}_{\text {heat }}, \mathrm{PEC}_{\text {light }}, \mathrm{E}_{\text {gen }}$ & & \\
\hline [38] & 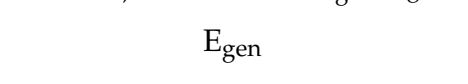 & & $\begin{array}{c}\text { CC, } \text { Sav }_{\text {electricity }}, \text { NPV, PI, } \\
\text { PBP }\end{array}$ \\
\hline [43] & $\mathrm{AeC}_{\text {light }}, \mathrm{AeC}_{\text {cool }}, \mathrm{AeC}_{\text {heat }}, \mathrm{AeC}$ & & \\
\hline [36] & NEB & VLT & CC, PBP, EPBT, EROEI \\
\hline [44] & $E_{\text {gen }}$, Sav $_{\text {light }}$, PEC, Sav PEC & & \\
\hline
\end{tabular}

\section{Materials and Methods}

In this research, a semi-transparent photovoltaics (STPV) evaluation system for building façade application was investigated through a combination of actual measurement and simulation results. Our study referenced an actual measurement outcome of a STPV system applied to a simple building design [41]. The DesignBuilder v6.1.6.5 simulation tool was used for building model validation against the measurement. After the simulation validation, a series of parametric analyses for different window-to-wall ratios (WWR), building orientations, and STPV types was performed using the simulation tool. Multi-criteria for a STPV building façade decision-making framework was attempted based on the simulation results by considering energy, comfort, and cost criteria. The methodological framework implemented in this research is shown in Figure 1. Yellow blocks indicate the simulation processes, whereas orange blocks indicate proposed and highlighted results.

In order to represent an actual building condition in a corresponding model, validation needs to be done by comparing actual measurement and simulation results $[20,41]$. American Society of Heating, Refrigerating and Air-Conditioning Engineers (ASHRAE) 14-2014 guideline recommends mean bias error (MBE) and cumulative variation of root mean square error (CV RMSE) as evaluation metrics for model comparison. There are two types of validation depending on the data source's time range, either hourly or monthly data. Hourly data validation metrics need to be less than $10 \%$ for MBE and 30\% for CV RMSE, whereas monthly data validation metrics are less than 5\% for MBE and 15\% for CV RMSE [45]. Calculation formula for MBE (Equation (1)) and CV RMSE (Equation (2)) are shown below $[45,46]$ :

$$
\operatorname{MBE}(\%)=\frac{\sum_{i=1}^{n}\left(m_{i}-s_{i}\right)}{\sum_{i=1}^{n}\left(m_{i}\right)}
$$




$$
\text { CV RMSE }=\frac{1}{\bar{m}} \sqrt{\frac{\sum_{i=1}^{N_{p}}\left(m_{i}-s_{i}\right)^{2}}{n-p}}
$$

where $m_{i}$ is the measured value, $s_{i}$ is the simulation value, $p$ is the number of the adjustable model parameters, and $n$ is the number of actual data points. However, the value of $p$ is advised to be zero for calibration purposes [47].

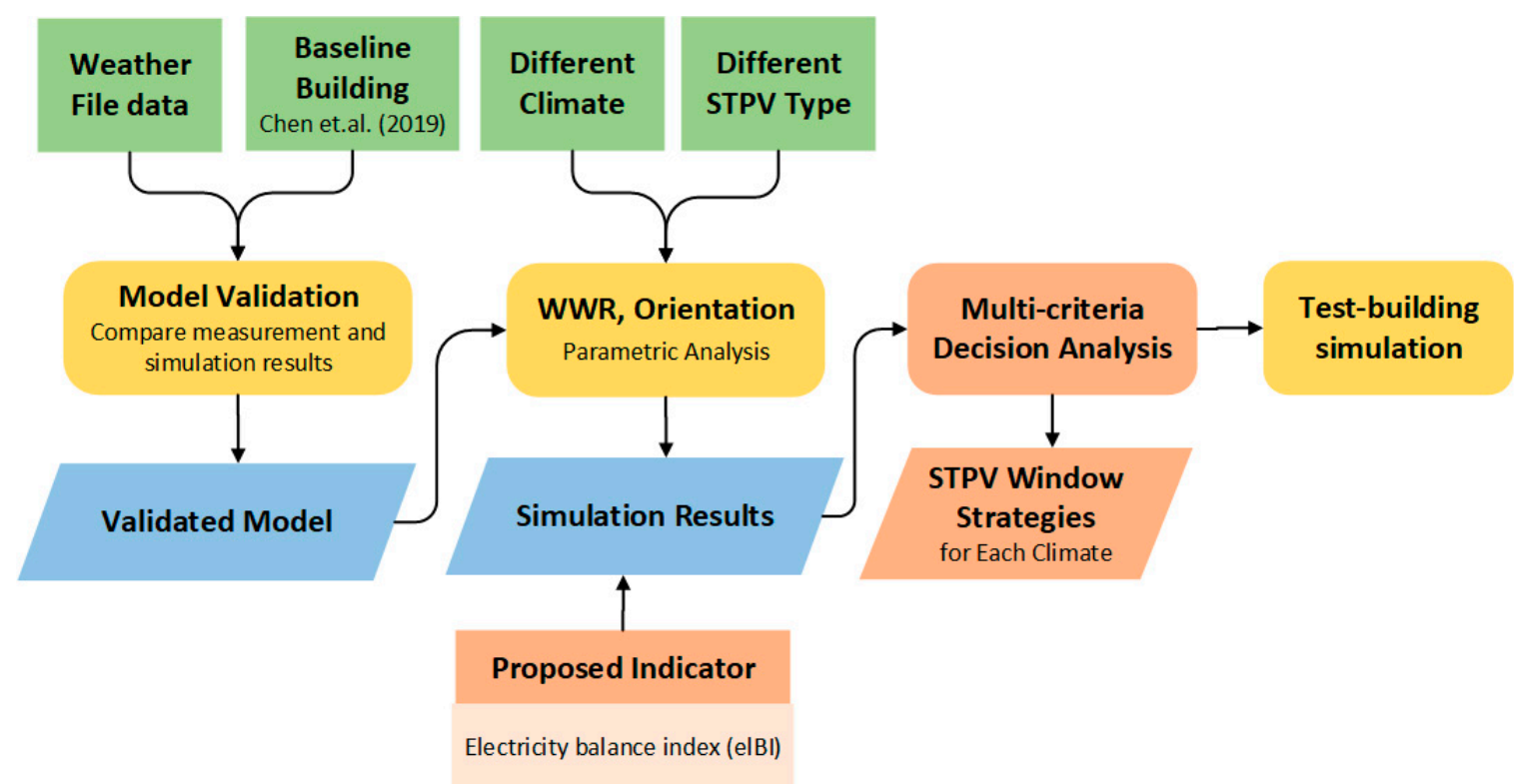

Figure 1. Diagrammatic representation of the methodological framework. Green blocks indicate input files, gold blocks represent DesignBuilder simulation processes, blue blocks indicate temporary results, and orange blocks represent proposed and highlighted results.

In this research, DesignBuilder v6.1.6.5, one of the commonly used building energy simulation tools, was utilized $[22,25,26]$. DesignBuilder is a building energy modeling software equipped with a graphical user interface based on an EnergyPlus dynamic simulation engine to run whole building energy simulations. EnergyPlus has several different simulation modules that could be connected to each other.

This study covered two different modeling stages, namely, baseline-building modeling and test-building modeling. In the baseline-building model, the building unit's energy consumption and STPV generation simulation results were compared to the actual measurement for validation. On the other hand, in the test-building model, monthly energy consumption simulation results were compared with monthly electricity bills for verification purposes. The values for building performance indicators were obtained through DesignBuilder simulation operations. Additionally, life-cycle cost (LCC) was calculated based on the simulation results to assess the building design alternatives' economic dimension.

In order to model STPV systems, the DesignBuilder simulation tool provides an energy generation modeling feature. A simple method was used to calculate potential solar energy generation by the STPV system. This method pertains to the flexibility to model any PV system while other empirical-based models are limited only to crystalline-based PVs [48]. A simple PV power generation equation can be written as Equation (3):

$$
P=A_{\text {surf }} \times f_{\text {active }} \times G_{T} \times \eta_{\text {cell }} \times \eta_{\text {inverter }}
$$

where $P$ is the electrical power output (Watt), $A_{\text {surf }}$ is the surface area $\left(\mathrm{m}^{2}\right), f_{\text {active }}$ is the fraction of surface area with active solar cells, $G_{T}$ is the total solar radiation incident on the STPV system $\left(\mathrm{W} / \mathrm{m}^{2}\right), \eta_{\text {cell }}$ is the efficiency of the solar cells, and $\eta_{\text {inverter }}$ is the efficiency of the inverter system. 


\subsection{Evaluated Building Configurations}

In this research, one of the precedent works' building model was used for the baselinebuilding model [41]. This building was located in Chengdu, Sichuan Province, China. The baseline-building model dimensions are as follows: $3 \mathrm{~m}$ for both width and length, $3 \mathrm{~m}$ for the opposite wall of the window-side height, $3.2 \mathrm{~m}$ for window-side wall height, and $1.34 \mathrm{~m}$ for the window height. For the wall and roof, this baseline building was using $75 \mathrm{~mm}$ thick sandwich rock wool board [49]. We authors referenced a similar product in an online market site to approximate the wall construction cost.

To verify the potential influence of the identified STPV façade strategies, a testbuilding-based simulation was carried out and analyzed. The selected building for this process was the Geo-Centrifuge Center (W16), a building located in KAIST, Daejeon, Korea. This building is a research facility characterized by an intense and diversified activity schedule. Detailed building-related data sets were acquired through the KAIST facility team and by referencing previous works [50]. Both of the building's physical configuration and its corresponding DesignBuilder model are shown in Figure 2.
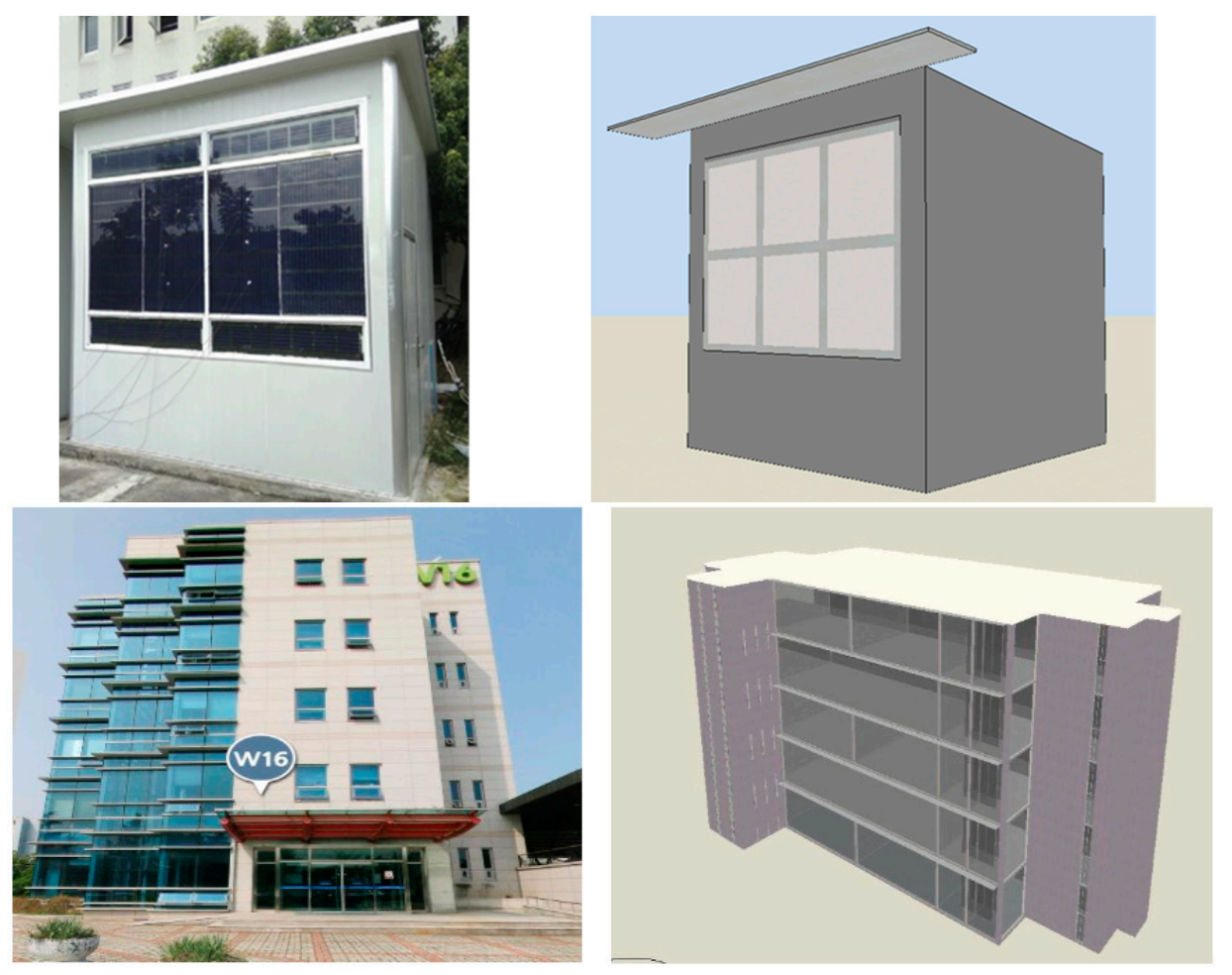

Figure 2. Baseline building actual configuration (top-left) [41] and corresponding DesignBuilder model (top-right). Test-building actual configuration (W16 building at KAIST) (bottom left) and corresponding DesignBuilder model (bottom right).

\subsection{Evaluated Climate Regions}

The Köppen climate classification system was referenced to select alternative building locations having different climate conditions. The Köppen climate classification mainly focuses on local temperature and precipitation data and suggests five main climatic regions, i.e., equatorial climate (A), arid climate (B), warm temperate climate (C), snow climate (D), and polar climate (E) [51]. Table 2 presents selected cities and their climatic characteristics based on Köppen climate classification. These selected cities were tested to determine the best climate-dependent strategies for STPV-applied window systems [11,39,52,53]. HDD refers to heating degree days, while CDD indicates cooling degree days. 
Table 2. Selected global locations and their climatic characteristics.

\begin{tabular}{|c|c|c|c|c|c|c|c|}
\hline Location & Latitude & Longitude & Climate & $\begin{array}{c}\text { HDD } \\
\left(\mathbf{1 8 . 3}{ }^{\circ} \mathrm{C}\right)\end{array}$ & $\begin{array}{c}\text { CDD } \\
\left(10^{\circ} \mathrm{C}\right)\end{array}$ & $\begin{array}{l}\text { Monthly Solar } \\
\text { Radiation } \\
\text { (Average } \pm \\
\text { std.Deviation) }\end{array}$ & $\begin{array}{c}\text { Electricity } \\
\text { Price } \\
\text { (US\$/kWh) }\end{array}$ \\
\hline $\begin{array}{l}\text { Chengdu, China } \\
\text { (baseline) }\end{array}$ & 30.667 & 104.017 & Cfa & 1422 & 2662 & $3588.33 \pm 1186.61$ & 0.081 \\
\hline Abu Dhabi, UAE & 24.417 & 54.65 & BWh & 24 & 6254 & $6037.67 \pm 1352.89$ & 0.02 \\
\hline Buenos Aires, Argentina & 34.817 & 58.517 & Csa & 1189 & 2524 & $4520.33 \pm 1797.41$ & 0.095 \\
\hline Beijing, China & 39.783 & 116.467 & Dwa & 2906 & 2199 & $4142.08 \pm 1448.84$ & 0.081 \\
\hline Cairo, Egypt & 30.1167 & 31.383 & BSh & 390 & 4276 & $5253.08 \pm 1777.24$ & 0.036 \\
\hline Incheon, South Korea & 37.467 & 126.55 & Dfa & 1920 & 2782 & $3222.5 \pm 1028.68$ & 0.11 \\
\hline Reykjavik, Iceland & 64.117 & 21.883 & Dfc & 4917 & 65 & $2129.5 \pm 1775.32$ & 0.16 \\
\hline Singapore & 1.367 & 103.967 & Af & 0 & 6374 & $4582.5 \pm 261.03$ & 0.182 \\
\hline Wellington, New Zealand & 41.283 & 174.767 & $\mathrm{Csb}$ & 1849 & 1218 & $3968.58 \pm 1987.73$ & 0.23 \\
\hline
\end{tabular}

\subsection{Evaluated Window Characteristics}

STPV-applied window system characteristics could be categorized into optical, thermal, and electrical characteristics. The optical characteristic is defined as the visible light transmittance (VLT). Thermal characteristics are represented by the thermal transmittance coefficient (U-value) and solar heat gain coefficient (SHGC). Lastly, electrical characteristics are quantified through maximum power output and efficiency of STPV $\left(\eta_{S T P V}\right)$. Those selected STPV-applied window modules are listed in Table $3[20,21,36]$.

Table 3. Selected commercial semi-transparent photovoltaics (STPV) systems and their characteristics $(1$ Euro $=1.19 \$, 1$ SGD $=0.74 \$)$.

\begin{tabular}{|c|c|c|c|c|c|c|}
\hline \multirow[b]{2}{*}{ Module } & \multicolumn{3}{|c|}{ Thermo-Optical Para \%meters } & \multicolumn{2}{|c|}{ Electrical Para \%meters } & \multirow[b]{2}{*}{ Price } \\
\hline & VLT (\%) & $\begin{array}{l}\text { U-Value } \\
\left(\mathrm{W} / \mathrm{m}^{2} \mathrm{~K}\right)\end{array}$ & SHGC & $\begin{array}{l}\text { Max. Power } \\
\left(\mathrm{Wp} / \mathrm{m}^{2}\right)\end{array}$ & $\eta_{S T P V}(\%)$ & \\
\hline Baseline & 20.0 & 2.281 & 0.380 & 86.06 & 10 & - \\
\hline Module A & 9.17 & 5.076 & 0.289 & 77.42 & 8.02 & US\$ 591 \\
\hline Module B & 5.19 & 4.795 & 0.413 & 55.94 & 5.90 & US\$ 232.245 \\
\hline Module C & 6.91 & 1.674 & 0.154 & 47.92 & 4.75 & US\$ 1215.74 \\
\hline Module D & 28.4 & 5.7 & 0.41 & 28 & 2.8 & US\$ 107.51 \\
\hline Module E & 26.7 & 5.2 & 0.37 & 28 & 2.8 & US\$ 121.75 \\
\hline Module F & 10.8 & 5.7 & 0.29 & 40 & 2.8 & US\$ 105.63 \\
\hline Module G & 80 & 5.5 & 0.8 & 39.56 & 11 & US\$ 59.40 \\
\hline
\end{tabular}

\subsection{STPV System Evaluation and Multi-Criteria Decision-Making Framework}

In this work, five objective function variables were chosen across energy, comfort, and cost dimensions. These objective function variables include an electricity balance index for the energy dimension; thermal discomfort, useful daylight illuminance (UDI), and annual sunlight exposure (ASE) for the comfort dimension; and LCC for the cost dimension. In the meantime, an electricity balance index (elBI) is newly proposed in this study. This index could represent the ratio between the generated electricity from STPV and total energy consumption. Equation (4) shows the way to calculate the elBI index.

$$
e l B I=\frac{\text { Electricity }_{S T P V}}{\text { Electricity }_{\text {Cool }}+\text { Electricity }_{\text {Heat }}+\text { Electricity }_{\text {Light }}}
$$

The thermal discomfort indicator was based on the ASHRAE 55-2004 acceptable environment range, assuming 0.5 clo for summer clothes and 1.0 clo for winter clothes. The acceptable range was defined using the operative temperature, dew-point temperature, and indoor humidity.

Visual comfort indicators were based on useful daylight illuminance (UDI) and annual sunlight exposure (ASE). UDI is the fraction of annual indoor horizontal daylight illuminance within a certain given range. In order to calculate this indicator, each of the 
analyzed periods needs to be divided into three bins depending on the defined lower and upper illuminance limits $[35,54]$.

Annual sunlight exposure (ASE) was also applied to identify potential glare and solar heat gain influencing visual comfort. This indicator measures the percentage of the area that receives 1000 lux for 250 occupied hours annually [55]. For both visual comfort indicators, the Leadership in Energy \& Environmental Design (LEED v4) standard for daylight requirements became the primary reference. It requires minimizing ASE and maximizing UDI, for which the lower limit is 300 lux and the upper limit is 3000 lux [56].

For the economic indicator, a life-cycle cost (LCC) calculation was applied by referencing previous works related to net-zero energy building evaluation [39]. LCC was also utilized in other works related to building energy optimization for active-passive design [11-13]. Equation (5) and Equation (6) below show the LCC calculation method.

$$
\begin{aligned}
& L C C=I C+\operatorname{USPW}(N, r d) \times E C \\
& \operatorname{USPW}(N, r d)=\frac{1-(1+r d)^{-N}}{r d}
\end{aligned}
$$

where $I C$ is the investment cost, $\operatorname{USPW}(N, r d)$ is the uniform series present worth factor, $E C$ is the annual energy cost for the selected strategy, $N$ is the study period, and $r d$ is the annual discount rate. Variables $N$ and $r d$ were assumed to be 30 years and $5 \%$, respectively. Then, $U S P W(30.5 \%)$ is equal to 15.37 years.

The weighting rates for each indicator are defined using an analytic hierarchy process (AHP) from the subjective comparison matrix. Thus, those weighting rates will be the input of the ranking method using the preference ranking organization method for enrichment of evaluations (PROMETHEE II). These techniques combinations will decide the best solution strategies in each location.

AHP is one of the multi-criteria decision-making support technique. This technique derives a scale from each variable-paired comparison. AHP covers decision elements or criteria matrix construction, comparison between each criterion, and consistency ratio calculation [57]. Comparison matrix significance is defined in Table 4, which shows the scaling and significance judgment for AHP.

Table 4. Numerical scale and significance judgement [57].

\begin{tabular}{cc}
\hline Value & Significance \\
\hline 1 & Equal importance \\
3 & Moderate importance of one over another \\
5 & Strong importance \\
7 & Very strong importance \\
9 & Extreme importance \\
$2,4,6,8$ & Intermediate values between the two adjacent judgments \\
\hline
\end{tabular}

PROMETHEE II is one of the outranking methods for multi-criteria analysis that was proposed by Brans, Vincke, and Mareschal (1986). PROMETHEE II provides a complete ranking based on multi-criteria net flow. This technique starts with pairwise comparisons between each criterion and calculation of the differences. The differences are translated into a preference degree depending on the selected preference functions. The multi-criteria preference degree is computed based on each comparison pairwise. Finally, positive outranking flows are calculated to define how the strategies outrank the others $[58,59]$.

PROMETHEE II has six different types of preference functions. In this work, a linear criterion function that depends on the indifference $(q)$ and preference $(p)$ threshold was applied. The indifference threshold is defined as 5\% and the preference threshold is $10 \%[11,12]$. For a tool calculating the PROMETHEE score, Python programming language was utilized based on precedent related literature [59]. 


\section{Evaluation Results and Discussion}

\subsection{Baseline-Building Model Simulation}

Figure 3 illustrates a comparison between the actual measurement data obtained from a precedent study [41] and the corresponding model output gained through DesignBuilder simulation. Firstly, lighting energy consumption identified by the simulation was counted up to $23.64 \mathrm{kWh}$. It was $1.5 \%$ higher than its actual value obtained by the field measurement. The observed trend for both cooling energy consumption and semi-transparent photovoltaic (STPV)-based energy generation showed a reversed pattern. Cooling energy consumption calculated by the simulation was $47.41 \mathrm{kWh}, 1.39 \%$ lower than the field measurement, and generated energy via the photovoltaic unit approximated through the simulation was $19.66 \mathrm{~kW}$, again $1.7 \%$ lower than the field measurement. Consequently, based on the model evaluation metrics described in the previous section, this baselinebuilding model simulation was validated [45].

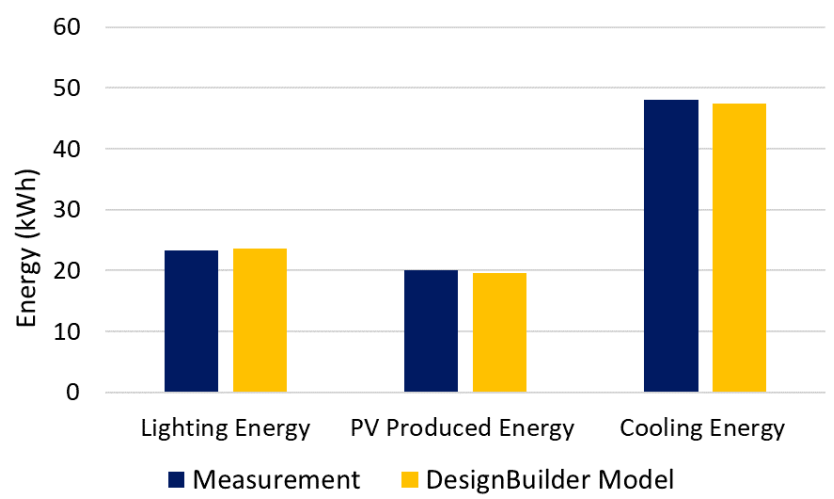

Figure 3. Comparison between measured and simulated energy consumption for the baseline building.

\subsubsection{Semi-Transparent PV Module Alternatives}

Other simulations were performed using the baseline building located in Chengdu with a WWR (window-to-wall ratio) of 50\% to compare various semi-transparent PV modules' energy performance profiles. Figure 4 illustrates such performance profiles considering different energy sectors such as lighting, heating, cooling, and electricity generation. Module B invoked the highest energy consumption while module E marked the least energy consumption. Module B required $1048 \mathrm{kWh}$ for lighting, $110 \mathrm{kWh}$ for heating, and $501 \mathrm{kWh}$ for cooling energy, annually. On the other hand, module E required $280 \mathrm{kWh}$ for lighting, $163 \mathrm{kWh}$ for heating, and $318 \mathrm{kWh}$ for cooling energy every year. The baseline STPV module and module G generated up to $200 \mathrm{kWh}$ per year regarding energy generation. Module D and module E generated approximately $56 \mathrm{kWh}$ per year, the least energy among all STPV modules. 


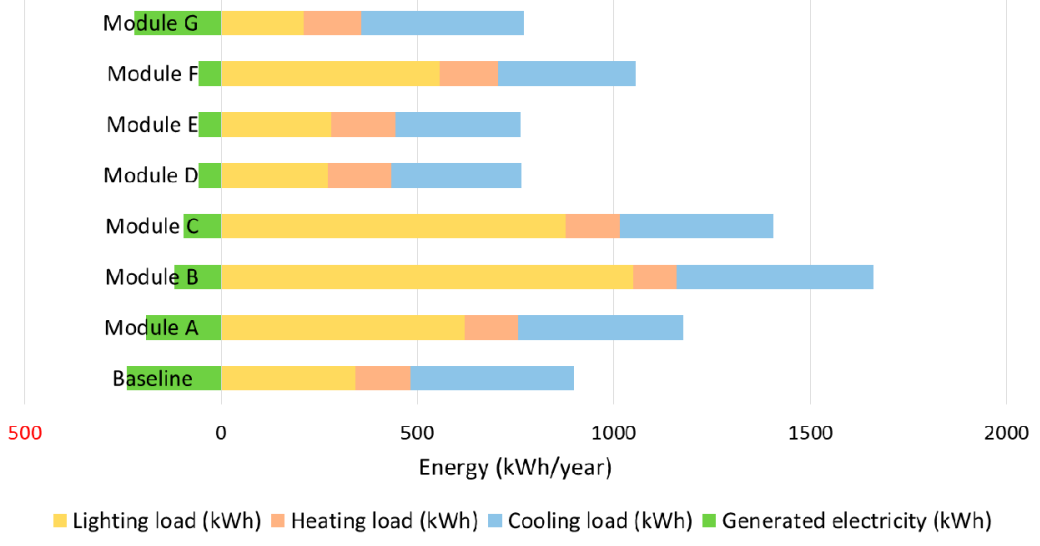

Figure 4. Energy consumption and generation profiles for the baseline building with different STPV modules.

Module A showed the highest maximum power generation characteristics, around $77.42 \mathrm{Wp} / \mathrm{m}^{2}$. However, module $\mathrm{A}^{\prime}$ s power generation was $13 \%$ less than module $\mathrm{G}$, which yielded $39.56 \mathrm{Wp} / \mathrm{m}^{2}$. This difference is ascribed to the fact that module G's efficiency is $11 \%$ while that of module $\mathrm{A}$ is $8.02 \%$. Even for the modules having the lowest efficiency (module D, E, and F), those modules generated only $74.5 \%$ less than module G. These findings also confirm that applying a higher efficiency module (Module G) would be beneficial for a smaller area of photovoltaics rather than using the module with the maximum power output (Module A). The window area of the baseline building is minimal considering its size, so choosing a higher efficiency module would be preferred.

As for STPVs' energy performance, the lighting, heating, and cooling energy consumption profile for each different type of STPV module is shown in Figure 4. As expected, lighting energy consumption turned out to be the most influential variable, which showed an $80 \%$ difference between the lowest (Module G) and the highest (Module B) lighting energy consumption amounts. In the meantime, the lowest and the highest cooling and heating energy consumption profiles for various STPV modules are 36.51\% and $32.2 \%$, respectively.

By reviewing the energy consumption profiles and STPV module characteristics in Table 3, it was revealed that lighting energy consumption is related to visible light transmission (VLT). The VLT for module B is $5.19 \%$, while module G is up to $80 \%$. This makes sense since higher VLT means that more daylight would enter the room; thus, lighting energy consumption could also be reduced.

Module B requires the highest cooling energy consumption in cooling energy, while module E requires the lowest. In the meantime, Module B shows the highest solar heat gain coefficient (SHGC) up to 0.413 , and this value indicates the solar heat transmission fraction from outside to inside. On the other hand, as for heating energy, module E requires the highest energy consumption while module B marks the lowest.

Figure 5 shows the evaluated STPV modules' thermal discomfort performances, which vary between 2260 and 2320 hours annually, which is equivalent to $25 \%$ of the total hours during one year ( 1 year equals 8760 hours). The difference between the lowest and the highest thermal discomfort hours is only $0.68 \%$, and the baseline STPV module provides the lowest number of discomfort hours while module $\mathrm{C}$ marks the highest. 


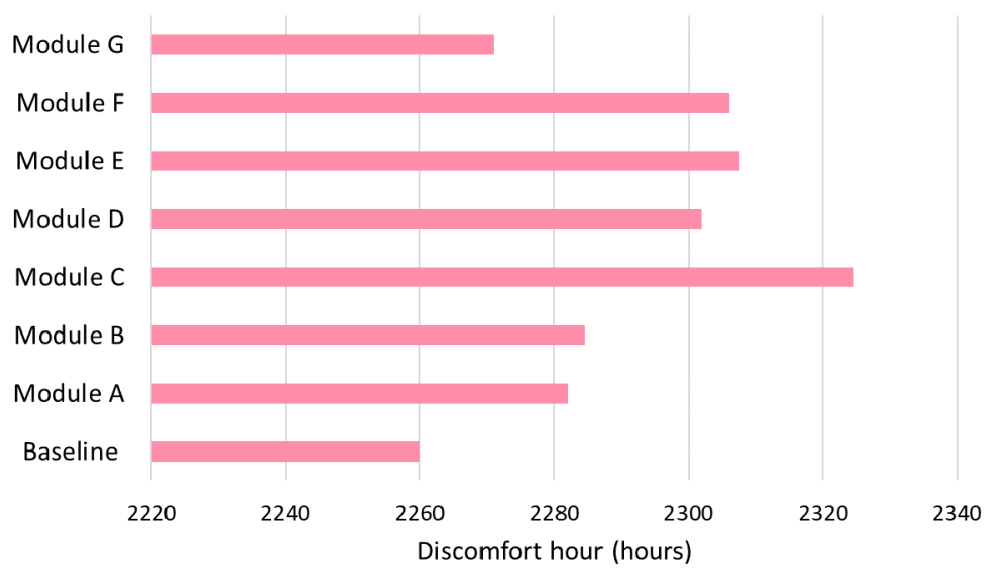

Figure 5. Thermal discomfort comparison for different STPV modules applied to the baseline building.

Discomfort hours are also related to the module characteristics described in Table 3 where module $C$ shows the highest discomfort hours. Module $C$ also is characterized by the lowest U-value and SHGC for its thermal characteristics. The gap between the lowest and the highest discomfort hours is not significant enough (around 2\%) compared to the energy consumption case.

Lastly, visual comfort is evaluated based on useful daylight illuminance (UDI) and annual sunlight exposure (ASE) indicators. Figure 6 shows comparative visual comfort profiles for the tested STPV modules. According to the referred standard [56], lower ASE and higher UDI yield the preferred visual comfort results. Three out of eight evaluated STPV modules passed the UDI standard level for $100 \%$ of the indoor area. On the other hand, only $3 \%$ of the indoor area passed the UDI standard requirement when module $C$ was applied.

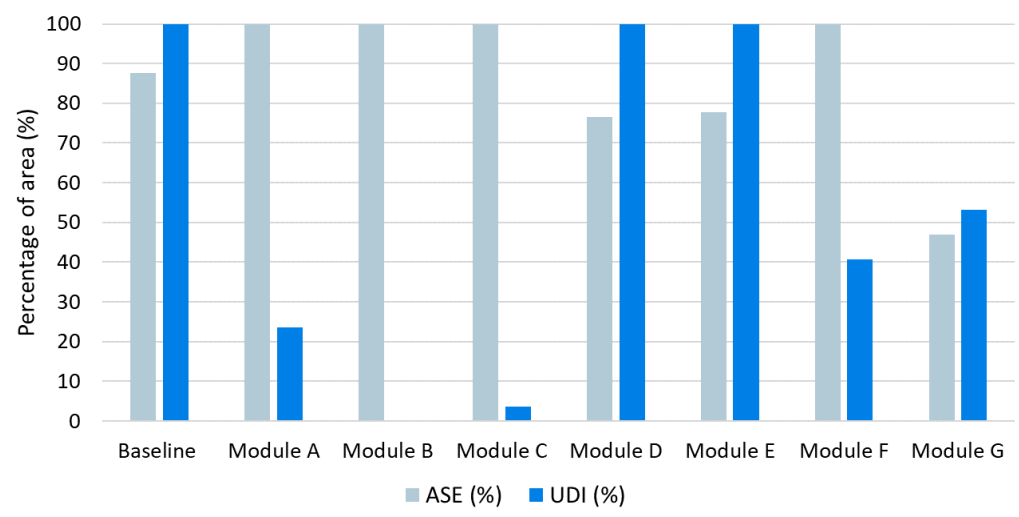

Figure 6. Daylighting performance comparison for the STPV modules applied to the baseline building.

The higher VLT described in Table 3 implies that more solar fraction could be introduced into the indoor environment. Higher VLT also indicates that the indoor illuminance gets higher, which is directly associated with UDI. On the other hand, UDI ranges between 300 and 3000 lux for $4380 \mathrm{~h}$, and ASE is counted when the illuminance level is higher than 1000 lux for $250 \mathrm{~h}$. This could mean that higher UDI and lower ASE implies that some part of the indoor environment has illuminance levels in the range of 300-1000 lux. Reversely, higher ASE and lower UDI implies that the illuminance levels at some points are higher than 1000 lux for $250 \mathrm{~h}$, but less than 4380 lux. 


\subsubsection{Optimality of Orientation and Window-Wall Ratio}

The newly proposed index, the electricity balance index (elBI), was examined to compare the baseline STPV module's performance in different geographical locations. Figure 7 shows the radial heat map in Chengdu, China (baseline building location), and Figure 8 illustrates a radial pie chart representing elBI indicator values calculated for different locations. Orientations were divided into eight categories, i.e., North, Northeast, East, Southeast, South, Southwest, West, and Northwest. Layers in the concentric circles represent varied window-to-wall ratios: $75 \%$ in the outer layer, $50 \%$ in the middle layer, and $25 \%$ in the inner layer. The color in each segment shows the value of the elBI indicator; a red color indicates higher values, and a blue color signifies lower values. A higher elBI value implies that the corresponding STPV module's electrical power generation is more likely to meet the building's energy consumption requirements.

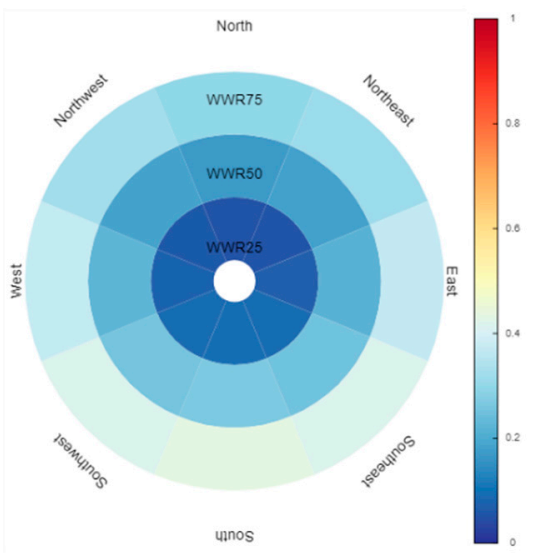

Figure 7. Graphical representation of electricity balance index (elBI) indicator in Chengdu (baseline).

The elBI indicator values can be plotted with a radial heat map as shown in Figures 7 and 8 . This indicator also shows the consistent value for each different location and gives an insight into a STPV's energy generation capability in relation to the building's total energy consumption. Results show that Chengdu (Figure 7), Beijing (Figure 8b), Buenos Aires (Figure 8c), and Wellington (Figure 8h) mark higher on the elBI than other locations. Intuitively, the elBI indicator has the advantage of giving insight into the energy consumption vs. energy generation profile of a specific STPV alternative while most of the precedent indicators could not address this.

The highest elBI values for Wellington and Buenos Aires are 0.848 and 0.74, respectively. According to the Köppen climate classification characteristic, Wellington and Buenos Aires are included in Group C, temperate/mesothermal climates. Wellington is a Mediterranean warm/cool summer climate (Group Csb), and Buenos Aires belongs to a Mediterranean hot summer climate (Group Csa). This study's identified findings support the fact that Mediterranean climate type (Group Cs or temperate dry summer) regions are the most suitable regions to apply STPV integrated façades efficiently among all tested climate type locations. 


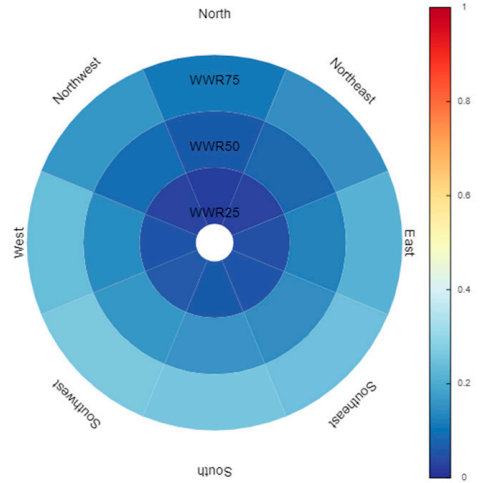

(a) Abu Dhabi

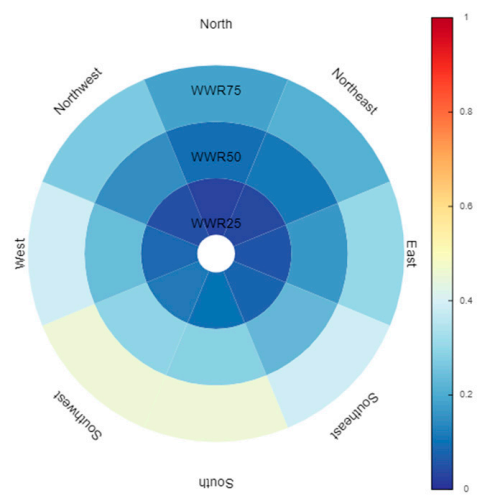

(d) Cairo

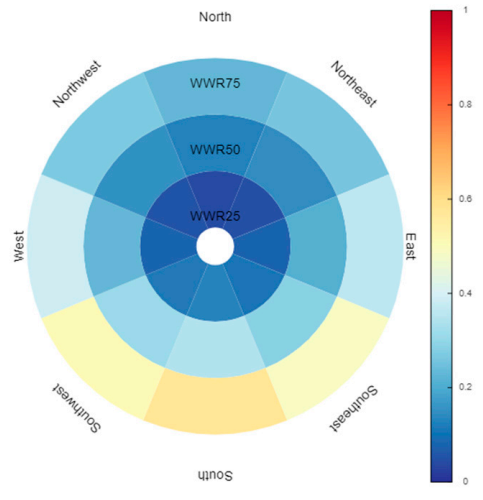

(b) Beijing

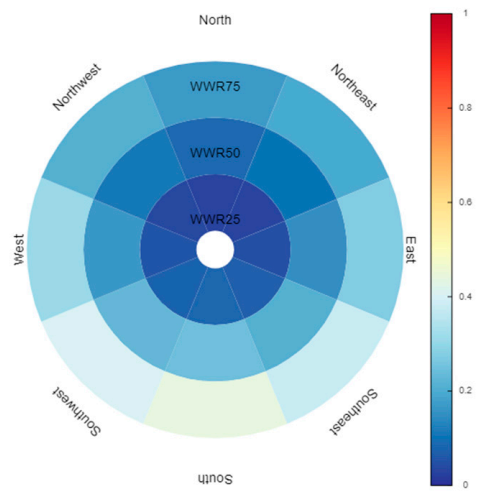

(e) Incheon

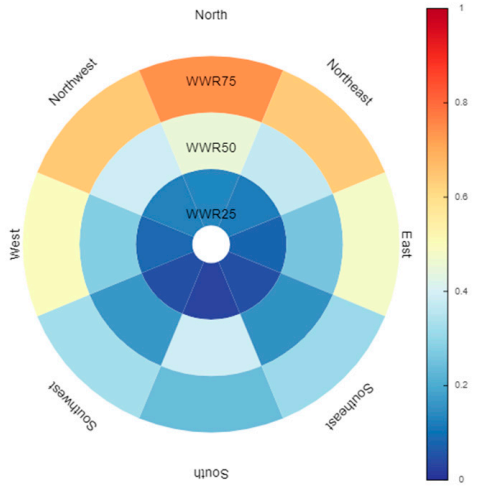

(c) Buenos Aires

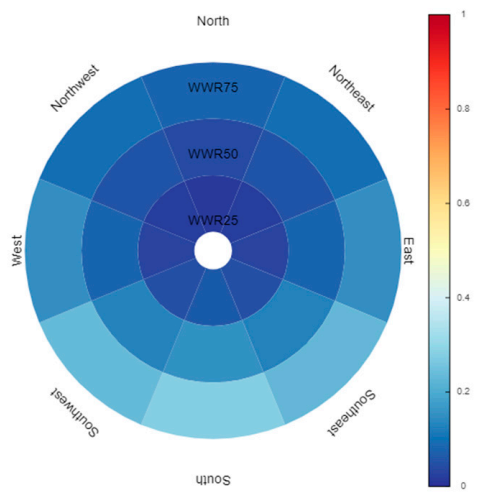

(f) Reykjavik

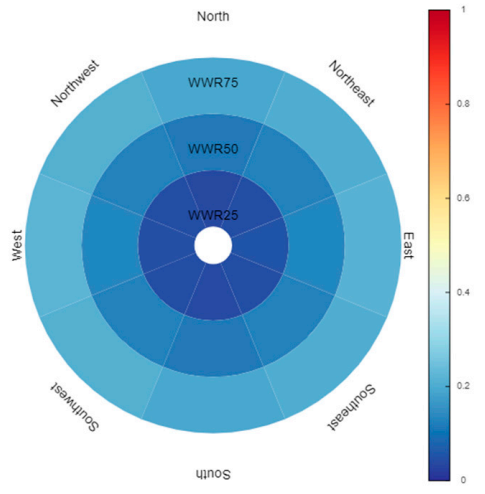

(g) Singapore

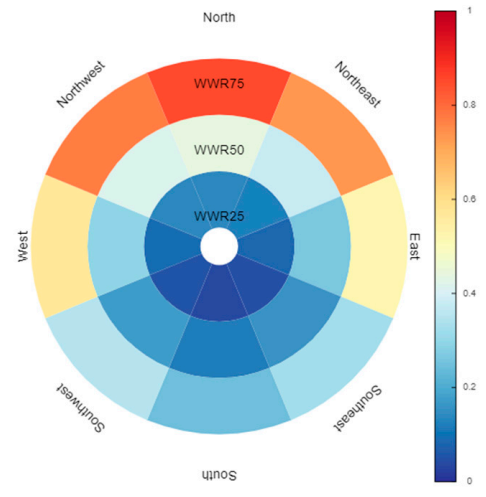

(h) Wellington

Figure 8. Graphical representation of elBI indicator for each evaluated building location.

\subsubsection{Multi-Criteria Decision-Making Analysis}

An analytic hierarchy process (AHP) was applied to assign weighting factors for each criterion. The pairwise comparison matrix in this AHP process is shown in Table 5. We reached almost the same weighting factor value for the cost indicator as a precedent study [60]. The highest weighting factor value assigned is life-cycle cost (LCC) at 0.46467; the next is the elBI indicator at 0.308702 . In the meantime, all comfort-related indicators (thermal discomfort, ASE, and UDI) share the same weighting factor value of 0.075543 . Even though this AHP technique is a subjective weighting model by its nature, we authors also considered previous studies that concerned multi-criteria decision-making issues in the built environment, especially building energy sectors. 
Table 5. Pairwise importance comparisons, weights, and optimization types for the performance indicators.

\begin{tabular}{cccccccc}
\hline Indicator & elBI & Discomfort & ASE & UDI & LCC & Weight & $\begin{array}{c}\text { Optimization } \\
\text { Type }\end{array}$ \\
\hline elBI & 1 & 5 & 5 & 5 & 0.333 & 0.309 & Maximization \\
Discomfort & 0.2 & 1 & 1 & 1 & 0.2 & 0.076 & Minimization \\
ASE & 0.2 & 1 & 1 & 1 & 0.2 & 0.076 & Minimization \\
UDI & 0.2 & 1 & 1 & 1 & 0.2 & 0.076 & Maximization \\
LCC & 3 & 5 & 5 & 5 & 1 & 0.465 & Minimization \\
\hline
\end{tabular}

The input parameters for PROMETHEE II detailed settings are shown in Table 5. Weighting factor values are derived from a series of pairwise comparisons through the AHP method. The optimization type is defined by the preferred minimization or maximization for each variable. To achieve an energy-efficient building, maximizing both electricity balance (maximizing energy generation while minimizing energy consumption) and UDI (for better daylighting) were attempted. On the other hand, thermal discomfort hours, ASE (for preventing glare and overheating), and LCC need to be minimized.

The final result of multi-criteria-based building integrated STPV decision-making for each region are shown in Table 6. Out of this result, module G turned out to be the most preferable STPV module across all tested climatic conditions. In terms of window size, a larger window size does not always guarantee better performance. Chengdu, $\mathrm{Abu}$ Dhabi, Buenos Aires, Cairo, and Wellington are identified as the regions where a 50\% WWR (window-wall ratio) is preferred over a larger one.

Table 6. Identified location-dependent multi-criteria STPV decision-making and detailed simulation outcomes.

\begin{tabular}{cccccccc}
\hline Region & WWR & Orientation & elBI & $\begin{array}{c}\text { Thermal Discomfort } \\
\text { (Hours) }\end{array}$ & ASE (\%) & UDI (\%) & LCC (USD) \\
\hline Chengdu & 0.50 & South & 0.286 & 2271 & 49.914 & 53.086 \\
Abu Dhabi & 0.50 & West & 0.159 & 2420.5 & 2.469 & 86.42 & 1414.817 \\
Beijing & 0.75 & South & 0.624 & 2147.5 & 22.222 & 45.679 & 1483.634 \\
Buenos Aires & 0.50 & Northeast & 0.507 & 1947.5 & 3.704 & 76.543 & 1182.644 \\
Cairo & 0.50 & Southeast & 0.269 & 1963 & 19.753 & 69.136 \\
Incheon & 0.75 & South & 0.636 & 2118 & 22.222 & 48.148 & 1179.495 \\
Reykjavik & 0.75 & Southeast & 0.348 & 2295 & 9.877 & 44.444 & 2729.166 \\
Singapore & 0.75 & South & 0.211 & 2610 & 77.778 & 45.679 & 4899.925 \\
Wellington & 0.50 & Northeast & 0.634 & 1579 & 13.58 & 67.901 \\
\hline
\end{tabular}

As illustrated in Table 6, each climatic group is associated with preferred characteristics for optimum STPV module selection. Those regions in Group A and B of Köppen climate classification are not suitable for STPV module installation judging from elBI and LCC indicator values. However, STPV would still be beneficial if the regions have an electricity cost of around US\$ $0.02-0.036 / \mathrm{kWh}$ as is shown by Abu Dhabi and Cairo cases. In Singapore, electricity cost is US\$ $0.182 / \mathrm{kWh}$, and it turns out that LCC is the highest among all solutions due to higher cooling energy consumption. Group $C$ marks the highest suitability for STPV module utilization, especially with lower CDD and HDD characteristics. Group D is still suitable, except for the Dfc (subarctic climate type) region or the locations showing high inequality between HDD and CDD.

Module $\mathrm{G}$ shows outstanding performance compared to other modules based on the decision-making analysis. Module $G$ turns out to be the most preferable module across all regions based on multi-criteria (energy, comfort, and cost) assessment. This module could also be customizable using mono-crystalline PV combined with ordinary clear glass. Characterized by the highest efficiency and lowest price among all evaluated STPV modules, this PV is selected as the best solution for all climate types. 
Table 7 summarizes critical information for considering a STPV integrated building façade in each selected global region. Underlined parts in Table 7 signify the primary consideration(s) for not recommending STPV system application in the region while bold parts in Table 7 indicate the bases for suggesting STPV installation for the specific location buildings.

Table 7. Primary considerations for STPV recommendation in varied global locations ( $\checkmark$ : recommended and $\times$ : not recommended).

\begin{tabular}{ccccc}
\hline Region & STPV & Electricity Cost & HDD & CDD \\
\hline Chengdu & $\checkmark$ & 0.081 & 1422 & 2662 \\
Abu Dhabi & $\times$ & 0.02 & $\underline{\mathbf{2 4}}$ & $\underline{6254}$ \\
Beijing & $\checkmark$ & 0.095 & 1189 & 2524 \\
Buenos Aires & $\checkmark$ & 0.081 & 2906 & 2199 \\
Cairo & $\times$ & 0.036 & $\underline{390}$ & $\underline{4276}$ \\
Incheon & $\checkmark$ & 0.11 & $\underline{1920}$ & $\underline{\mathbf{4 9 1 7}}$ \\
Reykjavik & $\times$ & $\underline{0.16}$ & $\underline{05}$ & $\underline{6374}$ \\
Singapore & $\times$ & $\underline{0.182}$ & $\mathbf{1 8 4 9}$ & $\mathbf{1 2 1 8}$ \\
Wellington & $\checkmark$ & 0.23 & & \\
\hline
\end{tabular}

Table 8 summarizes previous studies' findings on recommendable WWR and orientation for typical glazing as well as our findings on the STPV integrated window's optimum WWR and orientation. A typical window tends to have a smaller size window and particular orientation to avoid overheating and glare problems. On the other hand, semi-transparent PV should compromise solar radiation for energy generation and energy consumption.

Table 8. Recommended window-to-wall ratio (WWR) and orientation profiles for typical and STPV integrated glazing systems in different regions.

\begin{tabular}{ccccc}
\hline \multirow{2}{*}{ Region } & \multicolumn{2}{c}{ Typical Glazing } & \multicolumn{2}{c}{ Semi-Transparent PV Glazing } \\
& WWR & Orientation & WWR & Orientation \\
\hline Chengdu & $<0.7[61]$ & North-South [61] & 0.50 & South \\
Abu Dhabi & $0.10-0.20[62]$ & North [62] & 0.50 & West \\
Beijing & $0.2-0.42[63]$ & South [63] & 0.75 & South \\
Buenos Aires & - & South [64] & 0.50 & Northeast \\
Cairo & $0.20[65]$ & North [65] & 0.50 & Southeast \\
Incheon & $0.40[66]$ & South [66] & 0.75 & South \\
Reykjavik & $0.50-0.60[67]$ & South [67] & 0.75 & Southeast \\
Singapore & $0.24[68]$ & North-South [68] & 0.75 & South \\
Wellington & $<0.30[69]$ & North [69] & 0.50 & Northeast \\
\hline
\end{tabular}

\subsection{Test-Building Model Simulation}

Baseline-building targeted STPV optimization described so far was identifying the rules for STPV application. Another iteration of analysis with a chosen test building was attempted for applying the derived rules acquired from the precedent process. Figure 9 compares actual measured electricity consumption and the corresponding DesignBuilder simulator-based model. This comparison focused on monthly electricity consumption in the W16 building at KAIST (from 2015 KAIST electricity consumption data) and total electricity consumption calculated using DesignBuilder, including cooling, heating, lighting, and other room-associated electricity consumption. Monthly comparisons were evaluated using standard modeling accuracy metrics, which revealed that MBE is $0.92 \%$, and CV RMSE is $12.83 \%$. The differences between actual measurements and simulation results were possibly caused by a fluctuating occupancy rate and additional building operation details. It was found out that some rooms usually used blind slats to reduce sunlight transmission into the room. Higher power consumption shown by the actual 
measurement in August and December were probably caused by higher research activity related to public or private sector projects. Research activity is closely related to the university's semester operation schedules and usually reduces during the semester (March-June and September-December) and increases during summer and winter breaks. Based on the model evaluation metrics described in the previous section, this test-building model simulation turns out to be valid [45].

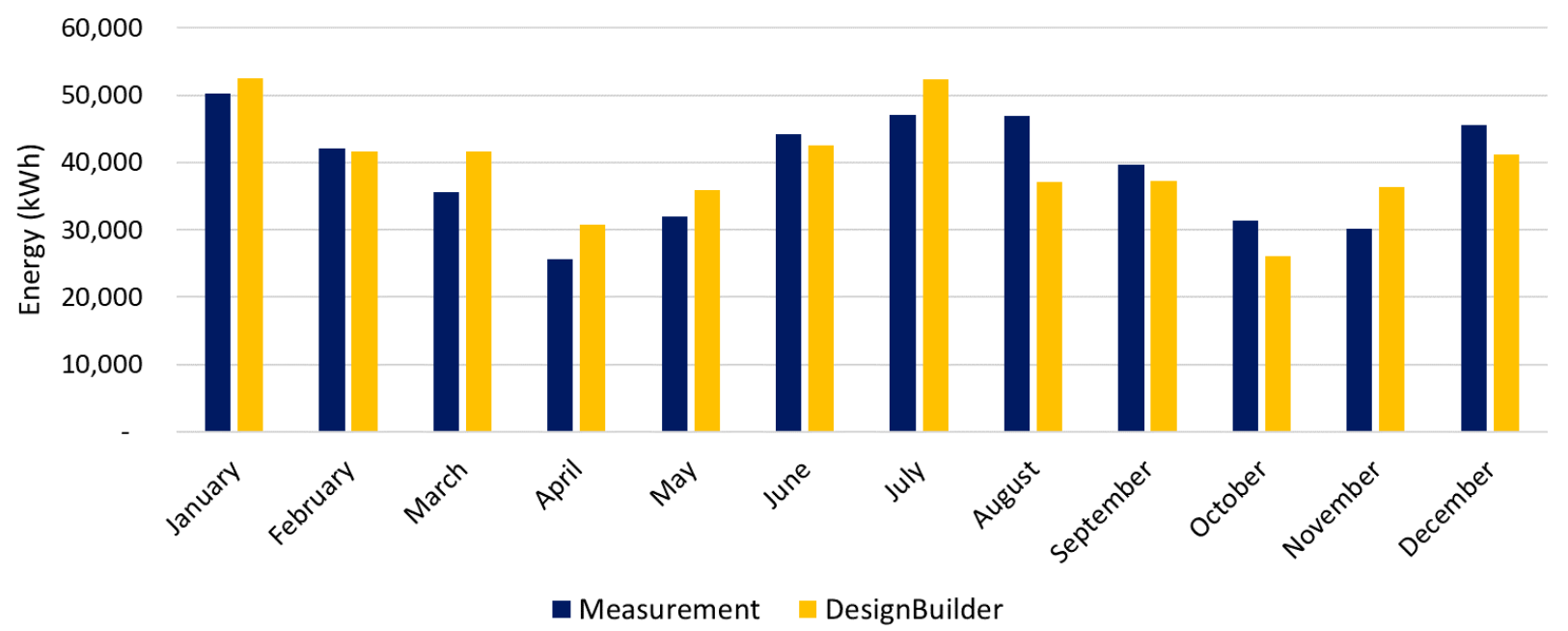

Figure 9. Comparison between measured and simulated energy consumption for a test building.

\subsubsection{Scenario-Based Applications of STPV to the Test Building}

STPV application decision-making options for the test building were generated by referring to Table 6, based explicitly on the strategy for Incheon. For South Korea, the best identified STPV strategy is characterized by a $75 \%$ WWR, module G, and south orientation. Several scenarios were tested in this part, assuming potential reconfigurations of the W16 building in KAIST, Korea. Table 9 shows additional scenarios with varied WWRs and orientation. 'As built' indicates the current design of the W16 building (35 degrees away from North-South orientation), assuming the same module $G$ applied for all scenarios. The STPV material would replace the largest side of the W16 building except for the bathroom glass part.

Table 9. Additionally evaluated scenarios for the test building STPV installation.

\begin{tabular}{ccc}
\hline Scenario & WWR (\%) & Orientation \\
\hline A & As built & As built \\
B & As built & North-South \\
C & 75 & As built \\
D & 75 & North-South \\
\hline
\end{tabular}

Figure 10 summarizes simulation outcomes for each tested scenario and includes energy generation, cooling, heating, and lighting energy consumption. Scenario A shows the highest electricity generation, while scenario D marks the lowest power production. The lowest cooling and heating energy consumption is associated with scenario $\mathrm{D}$ and scenario B, respectively. The same lighting energy consumption across all tested scenarios was identified, and these scenarios did not include any lighting control systems for indoor spaces. 


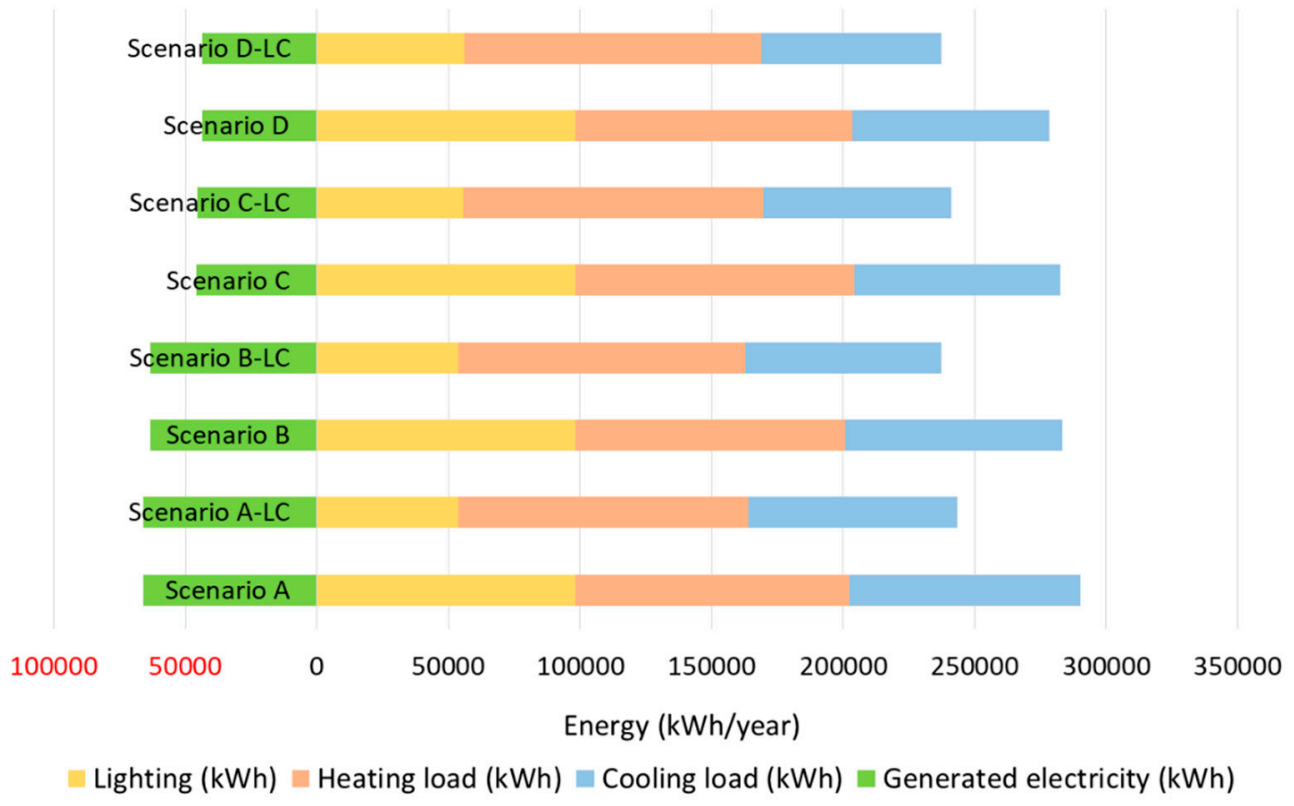

Figure 10. Energy performance profiles with and without ON/OFF lighting control scenario for the test building.

\subsubsection{Additional Lighting Control Strategy for STPV Performance Enhancement}

In addition to the stated findings, additional scenarios are explored concerning the lighting control system included in Table 7 with ' $L C$ ' extension, shown in Figure 10. This lighting control scheme is a simple ON/OFF control with an illuminance threshold of 300 lux. Lighting energy consumption for all scenarios was reduced to $40 \%$ after implementing an ON/OFF based lighting control scheme.

Surprisingly enough, scenario A-LC reduces lighting energy consumption up to $45.5 \%$, which is the highest percentage among all evaluated scenarios. Scenario A and A-LC also marked the highest electricity generation by the STPV panel.

It was found that a smart lighting control system could play a crucial role for an STPV integrated building façade's energy performance by being combined with well-thought-out enclosure components.

Figure 11 shows comparative elBI indicator profiles of the different STPV and lighting control system applications for the test building. Scenario A-LC shows the highest elBI of 0.27 , while scenario D marks the lowest. All additional lighting control scenarios show a minimum of 0.026 (with 75\% WWR) and a maximum of 0.043 (with 100\% WWR), higher elBI values than those not using the lighting control mechanism.

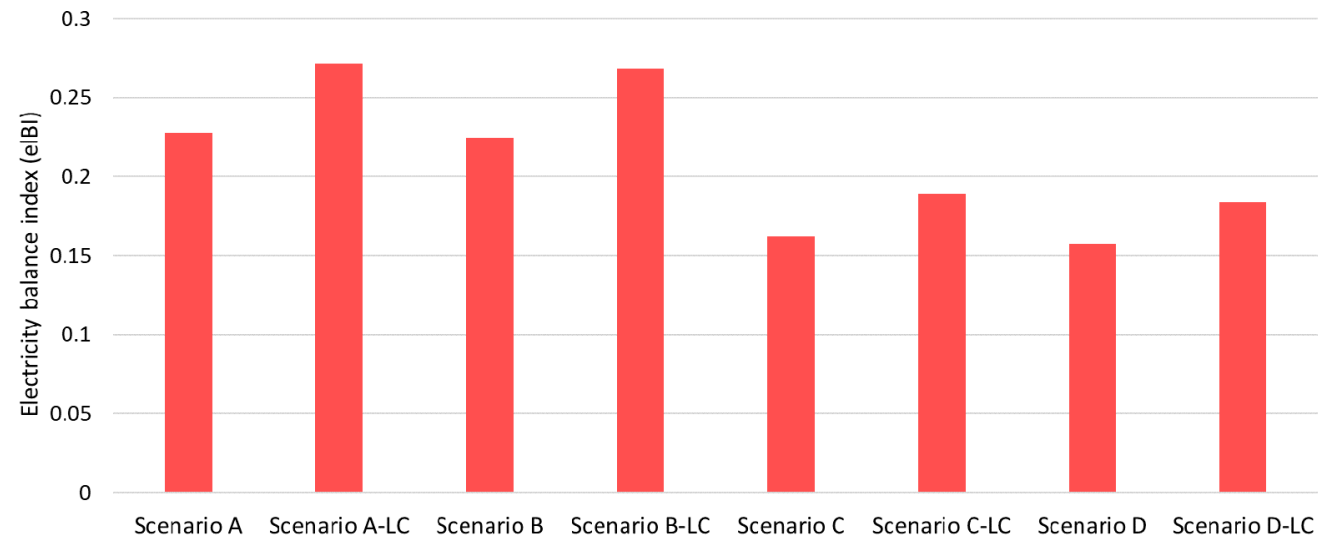

Figure 11. elBI value variations when an ON/OFF lighting control is added to the test building. 


\section{Conclusive Remarks}

This research explored the potential of a semi-transparent photovoltaic (STPV) system for an emerging high-performance building façade element applicable across various climatic locations. For that purpose, simulation model validation, STPV-related parametric analysis, and multi-criteria decision-making analysis were performed to acquire insightful rules of thumb for a successful deployment of an STPV system to differently located buildings. Climate-dependent STPV installation solutions are identified in reference to the Köppen climate classification framework. An optimum window-to-wall ratio (WWR) and orientation were recommended for a successful STPV integrated building façade across various global locations. Judging from the outcomes of the STPV integrated building performance evaluations across nine different global locations, the Mediterranean climate group (Group Csa and Csb) of the Köppen climate classification turns out to be the most suitable region for STPV application, especially considering elBI criteria. This finding does not perfectly match the claim of a precedent research study on PV system performance [70]. However, the authors of this study noted that general PV and STPV might have different behavioral characteristics when integrated into a building façade.

As for energy consumption, lighting energy consumption appeared to be the most critical variable for STPV applications. In order to address this issue, a lighting control strategy is suggested using a simple ON/OFF lighting control which could improve the elBI value by 0.026 (with 75\% WWR) or up to 0.043 (with 100\% WWR). This elBI value could also be varied depending on the location, window size, and STPV module type.

The primary findings identified through this research would be beneficial for energyefficient building design decision-making. In relation to the precedent literature review presented in Table 1, this research attempted to fill the gap for genuine multi-criteria decision-making for STPV application to the buildings in different locations. These findings also strengthen the importance of early design decision-making to identify the optimum building façade integrated with STPV that significantly differs from typical windows.

A set of weighting criteria and a proposed index, the elBI, suggested through this research could be applied to an early design of a building integrated photovoltaic (BIPV) façade. Furthermore, the generic strategy identified for each climate type described in Tables 8 and 9 could provide insightful guides for developing an effective BIPV application to the buildings in different global regions. Our findings could also contribute to developing an energy prosumer building design solution and climate-dependent optimum building passive design by being combined with energy generation through building skin.

Author Contributions: Conceptualization, G.R.S. and S.C.; methodology, G.R.S.; software, G.R.S.; validation, G.R.S., H.P., and S.C.; formal analysis, G.R.S.; resources, H.P.; data curation, H.P.; writingoriginal draft preparation, G.R.S.; writing-review and editing, G.R.S. and S.C.; supervision, S.C.; funding acquisition, S.C. All authors have read and agreed to the published version of the manuscript.

Funding: This work is supported by the Korea Agency for Infrastructure Technology Advancement (KAIA) grant funded by the Ministry of Land, Infrastructure and Transport (Grant 21PIYR-B15327703). This work is also financially supported by Korea Ministry of Land, Infrastructure and Transport (MOLIT) as "Innovative Talent Education Program for Smart City".

Institutional Review Board Statement: Not applicable.

Informed Consent Statement: Not applicable.

Data Availability Statement: The numerical model simulations upon which this study is based are too large to archive or to transfer. Instead, critical information is provided to replicate the simulations, if necessary.

Conflicts of Interest: The authors declare no conflict of interest. 


\section{References}

1. International Energy Agency (IEA) World Energy Outlook. Available online: https://www.iea.org/topics/world-energy-outlook (accessed on 21 September 2020).

2. Aksamija, A. Sustainable Facades: Design Methods for High-Performance Building Envelopes; John Wiley \& Sons, Inc.: Hoboken, NJ, USA, 2013; ISBN 978-1-118-45860-0.

3. Setyantho, G.R.; Chang, S. Identification of Primary Factors Influencing Energy Consumption Patterns of Commercial and Residential Buildings. kieae 2020, 20, 21-30. [CrossRef]

4. Lai, C.-M.; Hokoi, S. Solar Façades: A Review. Build. Environ. 2015, 91, 152-165. [CrossRef]

5. Biyik, E.; Araz, M.; Hepbasli, A.; Shahrestani, M.; Yao, R.; Shao, L.; Essah, E.; Oliveira, A.C.; del Caño, T.; Rico, E.; et al. A Key Review of Building Integrated Photovoltaic (BIPV) Systems. Eng. Sci. Technol. Int. J. 2017, 20, 833-858. [CrossRef]

6. Attoye, D.; Aoul, K.T.; Hassan, A. A Review on Building Integrated Photovoltaic Façade Customization Potentials. Sustainability 2017, 9, 2287. [CrossRef]

7. Moghtadernejad, S.; Mirza, M.S.; Chouinard, L.E. Façade Design Stages: Issues and Considerations. J. Archit. Eng. 2019, 25, 04018033. [CrossRef]

8. Wang, J.-J.; Jing, Y.-Y.; Zhang, C.-F.; Zhao, J.-H. Review on Multi-Criteria Decision Analysis Aid in Sustainable Energy DecisionMaking. Renew. Sustain. Energy Rev. 2009, 13, 2263-2278. [CrossRef]

9. Siksnelyte-Butkiene, I.; Zavadskas, E.K.; Streimikiene, D. Multi-Criteria Decision-Making (MCDM) for the Assessment of Renewable Energy Technologies in a Household: A Review. Energies 2020, 13, 1164. [CrossRef]

10. Turcksin, L.; Bernardini, A.; Macharis, C. A Combined AHP-PROMETHEE Approach for Selecting the Most Appropriate Policy Scenario to Stimulate a Clean Vehicle Fleet. Procedia Soc. Behav. Sci. 2011, 20, 954-965. [CrossRef]

11. Harkouss, F.; Fardoun, F.; Biwole, P.H. Passive Design Optimization of Low Energy Buildings in Different Climates. Energy 2018, 165, 591-613. [CrossRef]

12. Harkouss, F.; Fardoun, F.; Biwole, P.H. Multi-Objective Optimization Methodology for Net Zero Energy Buildings. J. Build. Eng. 2018, 16, 57-71. [CrossRef]

13. Harkouss, F.; Fardoun, F.; Biwole, P.H. Optimal Design of Renewable Energy Solution Sets for Net Zero Energy Buildings. Energy 2019, 179, 1155-1175. [CrossRef]

14. An, H.; Yoon, J.; An, Y.; Heo, E. Heating and Cooling Performance of Office Buildings with A-Si BIPV Windows Considering Operating Conditions in Temperate Climates: The Case of Korea. Sustainability 2018, 10, 4856. [CrossRef]

15. Chae, Y.T.; Kim, J.; Park, H.; Shin, B. Building Energy Performance Evaluation of Building Integrated Photovoltaic (BIPV) Window with Semi-Transparent Solar Cells. Appl. Energy 2014, 129, 217-227. [CrossRef]

16. Cheng, Y.; Gao, M.; Dong, J.; Jia, J.; Zhao, X.; Li, G. Investigation on the Daylight and Overall Energy Performance of SemiTransparent Photovoltaic Facades in Cold Climatic Regions of China. Appl. Energy 2018, 232, 517-526. [CrossRef]

17. Huang, J.; Chen, X.; Yang, H.; Zhang, W. Numerical Investigation of a Novel Vacuum Photovoltaic Curtain Wall and Integrated Optimization of Photovoltaic Envelope Systems. Appl. Energy 2018, 229, 1048-1060. [CrossRef]

18. Lee, H.M.; Yoon, J.H.; Kim, S.C.; Shin, U.C. Operational Power Performance of South-Facing Vertical BIPV Window System Applied in Office Building. Solar Energy 2017, 145, 66-77. [CrossRef]

19. Liao, W.; Xu, S. Energy Performance Comparison among See-through Amorphous-Silicon PV (Photovoltaic) Glazings and Traditional Glazings under Different Architectural Conditions in China. Energy 2015, 83, 267-275. [CrossRef]

20. Mesloub, A.; Albaqawy, G.A.; Kandar, M.Z. The Optimum Performance of Building Integrated Photovoltaic (BIPV) Windows Under a Semi-Arid Climate in Algerian Office Buildings. Sustainability 2020, 12, 1654. [CrossRef]

21. Ng, P.K.; Mithraratne, N.; Kua, H.W. Energy Analysis of Semi-Transparent BIPV in Singapore Buildings. Energy Build. 2013, 66, 274-281. [CrossRef]

22. Olivieri, L.; Caamaño-Martín, E.; Moralejo-Vázquez, F.J.; Martín-Chivelet, N.; Olivieri, F.; Neila-Gonzalez, F.J. Energy Saving Potential of Semi-Transparent Photovoltaic Elements for Building Integration. Energy 2014, 76, 572-583. [CrossRef]

23. Peng, J.; Curcija, D.C.; Lu, L.; Selkowitz, S.E.; Yang, H.; Zhang, W. Numerical Investigation of the Energy Saving Potential of a Semi-Transparent Photovoltaic Double-Skin Facade in a Cool-Summer Mediterranean Climate. Appl. Energy 2016, 165, 345-356. [CrossRef]

24. Salameh, T.; Assad, M.E.H.; Tawalbeh, M.; Ghenai, C.; Merabet, A.; Öztop, H.F. Analysis of Cooling Load on Commercial Building in UAE Climate Using Building Integrated Photovoltaic Façade System. Solar Energy 2020, 199, 617-629. [CrossRef]

25. Elghamry, R.; Hassan, H.; Hawwash, A.A. A Parametric Study on the Impact of Integrating Solar Cell Panel at Building Envelope on Its Power, Energy Consumption, Comfort Conditions, and CO2 Emissions. J. Clean. Prod. 2020, 249, 119374. [CrossRef]

26. Farghaly, Y.; Hassan, F. A Simulated Study of Building Integrated Photovoltaics (BIPV) as an Approach for Energy Retrofit in Buildings. Energies 2019, 12, 3946. [CrossRef]

27. Cannavale, A.; Hörantner, M.; Eperon, G.E.; Snaith, H.J.; Fiorito, F.; Ayr, U.; Martellotta, F. Building Integration of Semitransparent Perovskite-Based Solar Cells: Energy Performance and Visual Comfort Assessment. Appl. Energy 2017, 194, 94-107. [CrossRef]

28. Preet, S.; Sharma, M.K.; Mathur, J.; Chowdhury, A.; Mathur, S. Performance Evaluation of Photovoltaic Double-Skin Facade with Forced Ventilation in the Composite Climate. J. Build. Eng. 2020, 101733. [CrossRef] 
29. Sorgato, M.J.; Schneider, K.; Rüther, R. Technical and Economic Evaluation of Thin-Film CdTe Building-Integrated Photovoltaics (BIPV) Replacing Façade and Rooftop Materials in Office Buildings in a Warm and Sunny Climate. Renew. Energy 2018, 118, 84-98. [CrossRef]

30. Fiorito, F.; Cannavale, A.; Santamouris, M. Development, Testing and Evaluation of Energy Savings Potentials of Photovoltachromic Windows in Office Buildings. A Perspective Study for Australian Climates. Solar Energy 2020, 205, 358-371. [CrossRef]

31. Lee, J.W.; Park, J.; Jung, H.-J. A Feasibility Study on a Building's Window System Based on Dye-Sensitized Solar Cells. Energy Build. 2014, 81, 38-47. [CrossRef]

32. Aranda-Mena, G.; Fong, T.P. Building Integrated Photovoltaic for Architectural Façades in Singapore. J. Sustain. Res. 2020, 2. [CrossRef]

33. Chauvel, P.; Collins, J.B.; Dogniaux, R.; Longmore, J. Glare from Windows: Current Views of the Problem. Light. Res. Technol. 1982, 14, 31-46. [CrossRef]

34. Wienold, J.; Christoffersen, J. Towards a New Daylight Glare Rating. In Proceedings of the 10th European Lighting Conference, Berlin, Germany, 19-21 September 2005; pp. 157-161.

35. Nabil, A.; Mardaljevic, J. Useful Daylight Illuminances: A Replacement for Daylight Factors. Energy Build. 2006, 38, 905-913. [CrossRef]

36. Ng, P.K.; Mithraratne, N. Lifetime Performance of Semi-Transparent Building-Integrated Photovoltaic (BIPV) Glazing Systems in the Tropics. Renew. Sustain. Energy Rev. 2014, 31, 736-745. [CrossRef]

37. Wong, L.T.; Mui, K.W.; Hui, P.S. A Multivariate-Logistic Model for Acceptance of Indoor Environmental Quality (IEQ) in Offices. Build. Environ. 2008, 43, 1-6. [CrossRef]

38. Ghazali, A.; Salleh, E.I.; Haw, L.C.; Mat, S.; Sopian, K. Performance and Financial Evaluation of Various Photovoltaic Vertical Facades on High-Rise Building in Malaysia. Energy Build. 2017, 134, 306-318. [CrossRef]

39. Krarti, M.; Ihm, P. Evaluation of Net-Zero Energy Residential Buildings in the MENA Region. Sustain. Cities Soc. 2016, 22, 116-125. [CrossRef]

40. Jin, Q.; Overend, M. A Comparative Study on High-Performance Glazing for Office Buildings. Intell. Build. Int. 2017, 9, 181-203. [CrossRef]

41. Chen, M.; Zhang, W.; Xie, L.; Ni, Z.; Wei, Q.; Wang, W.; Tian, H. Experimental and Numerical Evaluation of the Crystalline Silicon PV Window under the Climatic Conditions in Southwest China. Energy 2019, 183, 584-598. [CrossRef]

42. Qiu, C.; Yang, H. Daylighting and Overall Energy Performance of a Novel Semi-Transparent Photovoltaic Vacuum Glazing in Different Climate Zones. Appl. Energy 2020, 276, 115414. [CrossRef]

43. Xu, S.; Liao, W.; Huang, J.; Kang, J. Optimal PV Cell Coverage Ratio for Semi-Transparent Photovoltaics on Office Building Façades in Central China. Energy Build. 2014, 77, 130-138. [CrossRef]

44. Do, S.L.; Shin, M.; Baltazar, J.-C.; Kim, J. Energy Benefits from Semi-Transparent BIPV Window and Daylight-Dimming Systems for IECC Code-Compliance Residential Buildings in Hot and Humid Climates. Solar Energy 2017, 155, 291-303. [CrossRef]

45. ASHRAE. ASHRAE Guideline 14-2014: Measurement of Energy, Demand, and Water Savings; ASHRAE: Atlanta, GA, USA, 2014.

46. Ruiz, G.; Bandera, C. Validation of Calibrated Energy Models: Common Errors. Energies 2017, 10, 1587. [CrossRef]

47. Reddy, A.; Maor, I.; Jian, S.; Panjapornporn, C. Procedures for Reconciling Computer-Calculated Results with Measured Energy Data; American Society of Heating, Refrigerating and Air-Conditioning Engineers: Atlanta, GA, USA, 2006; p. 2.

48. Griffith, B.T.; Ellis, P.G. Photovoltaic and Solar Thermal Modeling with the EnergyPlus Calculation Engine; National Renewable Energy Lab.: Denver, CO, USA, 2004; p. 8.

49. Wang, W.; Zhang, W.; Xie, L.; Wu, Y.; Tian, H.; Zheng, L. Experimental Assessment of the Energy Performance of a Double-Skin Semi-Transparent PV Window in the Hot-Summer and Cold-Winter Zone of China. Energies 2018, 11, 1700. [CrossRef]

50. Poddar, S.; Park, D.Y.; Chang, S. Simulation Based Analysis on the Energy Conservation Effect of Green Wall Installation for Different Building Types in a Campus. Energy Procedia 2017, 111, 226-234. [CrossRef]

51. Rubel, F.; Kottek, M. Observed and Projected Climate Shifts 1901-2100 Depicted by World Maps of the Köppen-Geiger Climate Classification. metz 2010, 19, 135-141. [CrossRef]

52. Weather Data I EnergyPlus. Available online: https://energyplus.net/weather (accessed on 13 October 2020).

53. International Energy Agency (IEA). Statistics Report: World Energy Prices. Overview; International Energy Agency (IEA): Paris, France, 2020.

54. Carlucci, S.; Causone, F.; De Rosa, F.; Pagliano, L. A Review of Indices for Assessing Visual Comfort with a View to Their Use in Optimization Processes to Support Building Integrated Design. Renew. Sustain. Energy Rev. 2015, 47, 1016-1033. [CrossRef]

55. Tabadkani, A.; Banihashemi, S.; Hosseini, M.R. Daylighting and Visual Comfort of Oriental Sun Responsive Skins: A Parametric Analysis. Build. Simul. 2018, 11, 663-676. [CrossRef]

56. US Green Building Council. LEED v4.1 Building Design and Construction; US Green Building Council: Washington, DC, USA, 2020.

57. Saaty, R.W. The Analytic Hierarchy Process - What It Is and How It Is Used. Math. Model. 1987, 9, 161-176. [CrossRef]

58. Brans, J.P.; Vincke, B.; Mareschal, B. How to Select and How to Rank Projects: The Promethee Method. Eur. J. Oper. Res. 1986, 24, 228-238. [CrossRef]

59. Sarmas, E.; Xidonas, P.; Doukas, H. Multicriteria Portfolio Construction with Python; Springer Optimization and Its Applications; Springer International Publishing: Cham, Switzerland, 2020; Volume 163, ISBN 978-3-030-53742-5. 
60. Fedorczak-Cisak, M.; Kotowicz, A.; Radziszewska-Zielina, E.; Sroka, B.; Tatara, T.; Barnaś, K. Multi-Criteria Optimisation of an Experimental Complex of Single-Family Nearly Zero-Energy Buildings. Energies 2020, 13, 1541. [CrossRef]

61. Shui, B.; Evans, M.; Lin, H.; Jiang, W.; Liu, B.; Song, B.; Somasundaram, S. Country Report on Building Energy Codes in China; Pacific Northwest National Laboratory (PNNL): Richland, WA, USA, 2009.

62. St Clair, P. Low-Energy Design in the United Arab Emirates-Building Design Principles. Environ. Design Guide 2009, JSTOR, 1-10.

63. Guo, Y.; Bart, D. Optimization of Design Parameters for Office Buildings with Climatic Adaptability Based on Energy Demand and Thermal Comfort. Sustainability 2020, 12, 3540. [CrossRef]

64. De Gastines, M.; Pattini, A.E. Window Energy Efficiency in Argentina - Determining Factors and Energy Savings Strategies. J. Clean. Prod. 2020, 247, 119104. [CrossRef]

65. Shahin, A.; Sumiyoshi, D. Building Energy Simulation towards Developing a Guideline for NZEBs in Egypt. Master's Thesis, Kyushu University, Fukuoka, Japan, 2018. [CrossRef]

66. Kim, S.-H.; Kim, S.-S.; Kim, K.-W.; Cho, Y.-H. A Study on the Proposes of Energy Analysis Indicator by the Window Elements of Office Buildings in Korea. Energy Build. 2014, 73, 153-165. [CrossRef]

67. Goia, F. Search for the Optimal Window-to-Wall Ratio in Office Buildings in Different European Climates and the Implications on Total Energy Saving Potential. Solar Energy 2016, 132, 467-492. [CrossRef]

68. Wang, L.; Wong Nyuk, H.; Li, S. Facade Design Optimization for Naturally Ventilated Residential Buildings in Singapore. Energy Build. 2007, 39, 954-961. [CrossRef]

69. Standards New Zealand. Thermal Insulation: Housing and Small Buildings; Standards New Zealand: Wellington, New Zealand, 2015; ISBN 978-1-86975-121-0.

70. Ascencio-Vásquez, J.; Brecl, K.; Topič, M. Methodology of Köppen-Geiger-Photovoltaic Climate Classification and Implications to Worldwide Mapping of PV System Performance. Solar Energy 2019, 191, 672-685. [CrossRef] 